\title{
Persistent Long-Term Facilitation at an Identified Synapse Becomes Labile with Activation of Short-Term Heterosynaptic Plasticity
}

\author{
Jiang-Yuan Hu and Samuel Schacher \\ Department of Neuroscience, Columbia University College of Physicians and Surgeons, and New York State Psychiatric Institute, New York, New York \\ 10032
}

\begin{abstract}
Short-term and long-term synaptic plasticity are cellular correlates of learning and memory of different durations. Little is known, however, how these two forms of plasticity interact at the same synaptic connection. We examined the reciprocal impact of short-term heterosynaptic or homosynaptic plasticity at sensorimotor synapses of Aplysia in cell culture when expressing persistent long-term facilitation (P-LTF) evoked by serotonin [5-hydroxytryptamine (5-HT)]. Short-term heterosynaptic plasticity induced by 5-HT (facilitation) or the neuropeptide FMRFa (depression) and short-term homosynaptic plasticity induced by tetanus [post-tetanic potentiation (PTP)] or low-frequency stimulation [homosynaptic depression (HSD)] of the sensory neuron were expressed in both control synapses and synapses expressing P-LTF in the absence or presence of protein synthesis inhibitors. All forms of short-term plasticity failed to significantly affect ongoing P-LTF in the absence of protein synthesis inhibitors. However, P-LTF reversed to control levels when either 5-HT or FMRFa was applied in the presence of rapamycin. In contrast, P-LTF was unaffected when either PTP or HSD was evoked in the presence of either rapamycin or anisomycin. These results indicate that synapses expressing persistent plasticity acquire a "new" baseline and functionally express short-term changes as naive synapses, but the new baseline becomes labile following selective activations - heterosynaptic stimuli that evoke opposite forms of plasticity — such that when presented in the presence of protein synthesis inhibitors produce a rapid reversal of the persistent plasticity. Activity-selective induction of a labile state at synapses expressing persistent plasticity may facilitate the development of therapies for reversing inappropriate memories.
\end{abstract}

\section{Introduction}

Long-term memories and their cellular correlates can be disrupted by interventions at various stages from induction to maintenance (McGaugh, 2000; Kandel, 2001). Persistent memories can be reversed when reactivated (reconsolidation) and paired with a manipulation: inhibitors of protein synthesis, specific kinases, or receptor activation (Nader et al., 2000; Kelly et al., 2003; Duvarci and Nader, 2004; Morris et al., 2006; Tronson et al., 2006; Boccia et al., 2007; Lubin and Sweatt, 2007; Zhang et al., 2010; Inda et al., 2011; Cai et al., 2012; Da Silva et al., 2013; Li et al., 2013). However, it is generally difficult to determine (1) whether the same synapses encoding the memory are also undergoing reversals in cellular properties to mediate the memory reversal, or (2) the properties of the stimulus at the reactivated

\footnotetext{
Received Jan. 9, 2014; revised Feb. 18, 2014; accepted Feb. 21, 2014.

Author contributions: J.-Y.H. and S.S. designed research; J.-Y.H. performed research; J.-Y.H. analyzed data; J.-Y.H. and S.S. wrote the paper.

The research was supported by National Institutes of Health (NIH) Grant MH 060387. Animals were provided by the National Center for Research for Aplysia at the University of Florida, Miami, FL, which is supported by NIH Grant RR-10294. We thank Drs. Larry Abbott and Amir Levine for their comments and suggestions, and Yang Chen for preparing cell cultures.

Correspondence should be addressed to Jiang-Yuan Hu, Department of Neuroscience, Columbia University College of Physicians and Surgeons, New York State Psychiatric Institute, 1051 Riverside Drive, New York, NY 10032. E-mail:jh2004@columbia.edu.

DOI:10.1523/JNEUROSCI.0098-14.2014

Copyright $\odot 2014$ the authors $\quad 0270-6474 / 14 / 344776-10 \$ 15.00 / 0$
}

synapses that evokes the labile state that underlies the reversal when paired with the manipulation.

In Aplysia, persistent long-term facilitation (P-LTF) of sensorimotor synapses is a cellular correlate of persistent long-term sensitization of defensive withdrawal reflexes, a form of fear memory (Kandel, 2001). Structural and functional changes at identified presynaptic sensory neurons and postsynaptic motor neurons contribute to P-LTF and to long-term sensitization of defensive withdrawal reflexes (Frost et al., 1985; Bailey and Chen, 1988; Glanzman et al., 1990; Trudeau and Castellucci, 1995; Mauelshagen et al., 1996, 1998; Zhu et al., 1997; Hatada et al., 2000; Sherff and Carew, 2002; Wainwright et al., 2002; Kim et al., 2003; Cai et al., 2008; Miniaci et al., 2008; Choi et al., 2011; Jin et al., 2012). The gill-siphon withdrawal behavior and sensorimotor synapses express bidirectional plasticity lasting minutes to weeks that reflect the nature, number, and temporal pattern of the stimuli (Pinsker et al., 1973; Castellucci et al., 1978; Montarolo et al., 1986, 1988; Dale et al., 1988; Bailey et al., 1992; Zhang et al., 1994; Sutton et al., 2002; Sharma et al., 2003; Sherff and Carew, 2004; Miniaci et al., 2008; Hu et al., 2011; Liu et al., 2013). Using this tractable system allows a direct examination of whether P-LTF becomes labile and undergoes reversal following specific forms of reactivation.

Cai et al. (2012) and Lee et al. (2012) reported that different forms of reactivation of Aplysia sensory neuron synapses-application of serotonin [5-hydroxytryptamine (5-HT)] or stimula- 


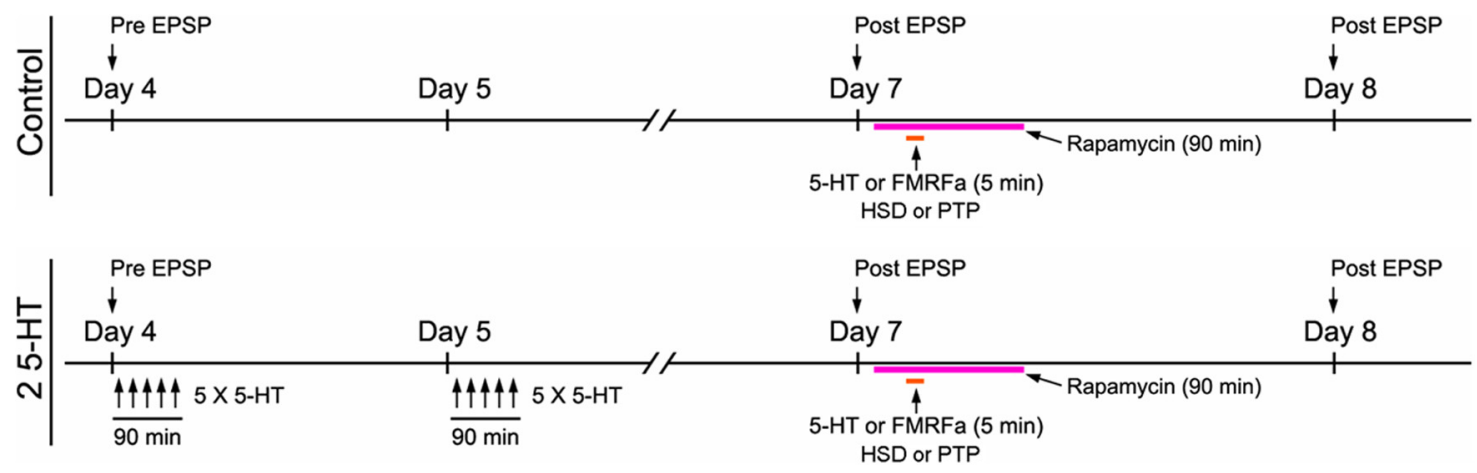

Figure 1. Experimental timeline to monitor the interactions between short-term synaptic plasticity and persistent LTF. EPSPs were recorded before (day 4 pre-EPSP) and after (days 7 and 8 post-EPSP) 25 -HT (bottom) or control treatments (top). 5-HT treatments ( 5 bath applications of $5 \mu \mathrm{m} 5$-HT each lasting 5 min at 20 min intervals) were given on days 4 and 5 , and produces P-LTF. After monitoring the EPSP amplitudes on day 7, cultures (controls or 25-HT) received different forms of short-term synaptic activations. Some cultures were exposed to a brief application (5 min) of 5-HT or FMRFa (heterosynaptic plasticity) in the absence or presence of rapamycin, while in other cultures sensory neurons were stimulated (homosynaptic plasticity) by either low-frequency stimulation ( 8 single action potentials at 20 sintervals) or a tetanus $(20 \mathrm{~Hz}$ for $2 \mathrm{~s}$ ) in the absence or presence of rapamycin. To monitor the response of short-term synaptic activation, EPSP amplitudes for some cultures were recorded $1 \mathrm{~min}$ after stimuli that produced different forms of short-term synaptic plasticity. On day 8, EPSPs were recorded to monitor the effect of different forms of short-term synaptic plasticity on persistent P-LTF or on control treatment.

tion of the sensory neuron-induce a labile state at the synapse such that when paired with protein synthesis inhibitors evoke a reversal in P-LTF. Does any activation of the synapses expressing persistent plasticity induce a labile state that could lead to reversals of persistent plasticity?

We systematically examined how two forms of short-term heterosynaptic plasticity or two forms of short-term homosynaptic plasticity affect sensorimotor synapses expressing P-LTF. Although significant short-term changes in synaptic strength were produced by the different stimuli as at naive synapses, P-LTF was unaffected. P-LTF rapidly reversed when protein synthesis inhibitor was present during and immediately after stimuli producing heterosynaptic plasticity, but not when inhibitor was present during and immediately after stimuli producing homosynaptic plasticity. Thus, the synapses expressing persistent plasticity functionally undergo short-term bidirectional changes when stimulated, and enter a labile state with selective (heterosynaptic) activation of the synapses.

\section{Materials and Methods}

Cell culture and electrophysiology. Sensory neurons were isolated from pleural ganglia dissected from adult animals (60-80 g; Aplysia californica, which are hermaphrodite) and motor neuron L7s were isolated from juvenile abdominal ganglia $(2 \mathrm{~g})$ and maintained in coculture for 7-9 d (Hu et al., 2011). The coculture contained one sensory neuron and one L7. Standard electrophysiological techniques were used to record EPSP amplitudes evoked in L7. L7s were held at $-80 \mathrm{mV}$, and EPSP amplitudes were recorded before and after various treatments at the indicated time points (Fig. 1). Each sensory neuron was stimulated with a brief depolarizing pulse to evoke an action potential using an extracellular electrode placed near the cell body of the sensory neuron. Cultures were fed every other day with medium containing $50 \%$ filtered hemolymph and 50\% L15 medium. Cultures were maintained at $18^{\circ} \mathrm{C}$.

Persistent long-term facilitation. Persistent long-term facilitation lasting more than a week was evoked as reported previously (Hu et al., 2011). After recording the baseline strength of sensorimotor synapses on day 4, some cultures were exposed to 2 consecutive days of 5 applications of 5-HT (2 5-HT; $5 \mu \mathrm{m}$; Sigma) each lasting $5 \mathrm{~min}$ at 20 min intervals (Fig. 1 ). Each application of 5-HT was washed out with solution containing $50 \%$ seawater and 50\% L15 medium. Cultures were fed medium containing 50\% filtered hemolymph and 50\% L15 medium before placement in the incubator. Control cultures received mock treatments. Synapse strengths were monitored on day 7 , day 8 , and, in some cases, day 9 .

Short-term heterosynaptic and homosynaptic plasticity. After recording EPSP strength on day 7 ( $48 \mathrm{~h}$ after the last 5-HT application to produce persistent LTF or control cultures treated with vehicle), cultures were exposed to either $5 \mu \mathrm{M} 5$-HT or $1 \mu \mathrm{M}$ FMRFa (Sigma) for 5 min to evoke short-term heterosynaptic plasticity (Fig. 1). EPSP amplitudes were reexamined on day 8 and in some cases on day 9. In some cultures, EPSPs were recorded $1 \mathrm{~min}$ after the start of washout of the neuromodulator to monitor the magnitude of short-term plasticity. In half of these cultures, EPSP amplitudes were also measured on day 8 and in some cases also on day 9. Other cultures were exposed to the protein synthesis inhibitor rapamycin ( $100 \mathrm{~nm}$; Calbiochem) for $90 \mathrm{~min}$ beginning $30 \mathrm{~min}$ before the brief application of neuromodulators or control applications. As above, EPSP amplitudes were re-examined on day 8 and in some cases on day 9. In some cultures, EPSP strength was monitored 1 min after the start of washout of the neuromodulators to monitor the magnitude of shortterm plasticity in the presence of rapamycin. In half of these cultures, EPSPs were also re-examined on day 8 and in some cases on day 9 .

The same general procedures were followed for short-term homosynaptic plasticity (Fig. 1). After recording EPSP amplitude on day 7, sensory neurons (control or 25 -HT treatment) were stimulated to fire a single action potential at $20 \mathrm{~s}$ intervals (eight stimuli) to produce homosynaptic depression (HSD). Other sensory neurons (control or 25-HT treatment) were stimulated at $20 \mathrm{~Hz}$ for $2 \mathrm{~s}$ to produce post-tetanic potentiation (PTP). Other cultures were exposed to $100 \mathrm{~nm}$ rapamycin or $10 \mu \mathrm{M}$ anisomycin (Calbiochem) for $90 \mathrm{~min}$ beginning $30 \mathrm{~min}$ before the stimuli evoking HSD, PTP, or controls. EPSP strength was monitored on day 8 and in some cases on day 9. To monitor the extent of PTP, synapse strength in some cultures was monitored $1 \mathrm{~min}$ after the tetanus presented either in the absence or presence of rapamycin. In half of these cultures, EPSPs were also re-examined on day 8 and in some cases on day 9.

Quantification and data analysis. All data are expressed as the mean \pm SEM produced by the indicated treatments. The EPSP amplitude was measured in millivolts. To measure the extent of persistent LTF, EPSP amplitude on day 4 was normalized as $100 \%$. The changes in EPSP amplitudes were measured by dividing the EPSP amplitudes on days $7-9$ by the EPSP amplitude on day 4, multiplied by $100 \%$. No change in amplitude is represented as $100 \%$. To measure the changes evoked by the brief exposure to 5-HT or FMRFa, and homosynaptic plasticity evoked by HSD or PTP, the initial EPSP amplitude on day 7 was normalized as $100 \%$. The change in EPSP amplitude associated with short-term plasticity is expressed by dividing the amplitude of each EPSP by the amplitude of the first EPSP measured on day 7 multiplied by $100 \%$. The brief application of 5-HT to sensorimotor synapses expressing P-LTF typically $(\sim 70 \%)$ resulted in an increase in synaptic strength that was expressed as an action potential in L7 (Fig. 2A). A second test was given $20 \mathrm{~s}$ later. This EPSP was assumed to be $40 \%$ lower, since this is the average decline associated with HSD (Fig. $3 A$ ). Thus, the strength of the synapse with 
short-term facilitation was determined (if an action potential was generated with the first test stimulus) as the amplitude of the second EPSP $\times 1.4$. A two-factor ANOVA (treatment $\times$ repeated measure or time) and a onefactor ANOVA (treatment) were used to assess overall significant differences, and the Scheffé's $F$ test was used to gauge significant differences between individual treatments.

\section{Results}

\section{Short-term plasticity is coexpressed} with persistent long-term facilitation

The sensorimotor synapse expresses P-LTF lasting more than a week (Hu et al., 2011). We examined whether bidirectional short-term heterosynaptic and homosynaptic plasticity are expressed at $48 \mathrm{~h}$ after the last application of 5-HT and whether the synaptic changes evoked by the different stimuli affected the persistence of the plasticity. After recording the EPSP on day 7 in control and 2 5-HTtreated cultures, the synapses were activated by a brief application of 5-HT (heterosynaptic facilitation), FMRFa (heterosynaptic depression), PTP (homosynaptic facilitation), or HSD (homosynaptic depression). In some cultures, short-term plasticity was evoked in the presence of protein synthesis inhibitors (rapamycin or anisomycin). The strengths of synapses were monitored $1 \mathrm{~min}$ after the application of either 5-HT or FMRFa, or after tetanus in the presence or absence of rapamycin to measure the extent of short-term plasticity. In half of these cultures EPSPs were also recorded 24-48 h later to monitor the maintenance of P-LTF. For these cultures, the additional test of synapse strength did not alter the maintenance of P-LTF or its potential reversal when rapamycin was present during the stimuli.

Short-term heterosynaptic plasticity was not affected at sensorimotor synapses expressing P-LTF (Fig. 2). A brief application of 5-HT evoked comparable increases in EPSP amplitude 1 min later in both naive synapses and synapses expressing P-LTF (Fig. $2 A$ ). The brief application of 5-HT produced an increase of $178 \pm$ $12.4 \%$ at synapses expressing P-LTF $(N=6)$ that was not significantly different $(p>0.9)$ than the increase of $176 \pm 10.2 \%$ in controls $(N=6)$. Similarly, a brief application of FMRFa resulted in a depression of the EPSP amplitude to $60 \pm 5.6 \%(N=6)$ at synapses expressing P-LTF that was not significantly different $(p>0.6)$ than the depression in the EPSP amplitude to $65 \pm$ $4.8 \%(N=6)$ in controls (Fig. $2 B)$. The average overall depression evoked by FMRFa at synapses expressing P-LTF resulted in synapse strength returning to the amplitude recorded on day 4 before the applications of 5-HT that evoked P-LTF $(102 \pm 5.1 \%)$. Thus, short-term heterosynaptic plasticity (bidirectional changes in EPSP amplitude) does not appear to be altered by the expression of P-LTF.

Short-term heterosynaptic plasticity at synapses expressing P-LTF was unaffected by the presence of rapamycin (Fig. 2). In
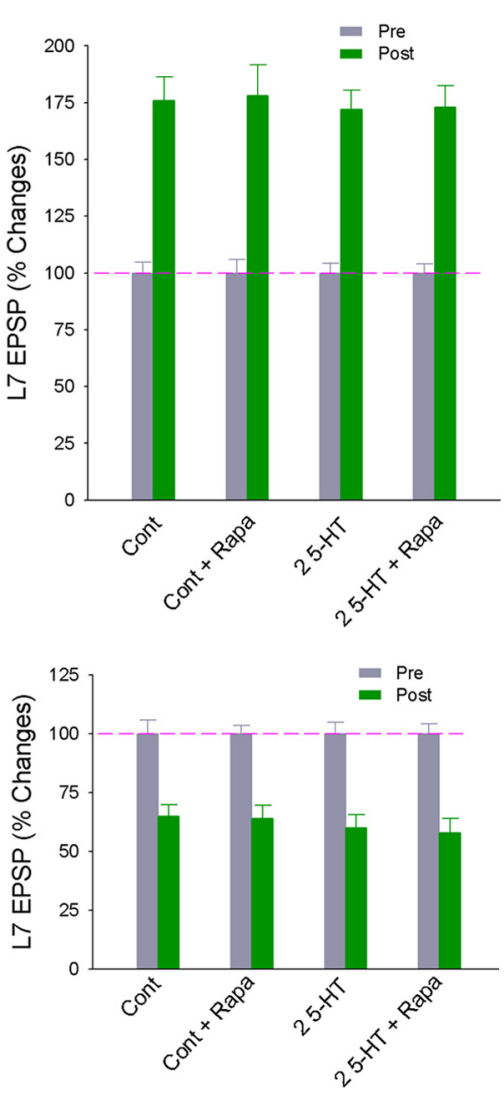

Figure 2. Persistent LTF did not affect the expression of short-term heterosynaptic plasticity. $\boldsymbol{A}$, Short-term synaptic facilitation induced by 5-HT was not affected by P-LTF expressed at the same synapses. Left, Sample traces of EPSPs evoked in L7 on day 7 before (Pre) and 1 min after (Post) a 5 min application of 5-HT at control synapses or synapses expressing P-LTF either in the atment $X$ repeated measures) indicated no significant effect on the expression of short-term facilitation evoked in each group application $F=436.097 ; p 0.9)$, but a one-factor ANOVA shows a significant facilitation in each group evoked by the brief 5 - $H$ ressed at the same synapses. Left, Sample traces of EPSPs evoked in L7 on day 7 before (Pre) and 1 min after (Post) a 5 min

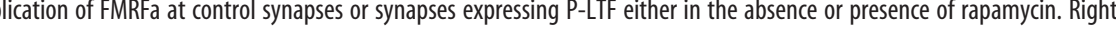
short-term depression with treatment ( $\mathrm{df}=3,20 ; F=2.494 ; p>0.08)$, but a one-factor ANOVA shows a significant depression evoked in each group by a brief application of FMRFa ( $F=1245.629, p<0.001$; see Results).

the presence of rapamycin, a brief application of 5-HT increased EPSP amplitude to $173 \pm 9.4 \%$ at synapses expressing P-LTF $(N=6)$, which was not significantly different $(p>0.9)$ than the increase of $178 \pm 13.7 \%$ evoked by 5 -HT at naive synapses in the presence of rapamycin $(N=5$; Fig. $2 A)$. Short-term depression evoked by FMRFa was also unaffected by the presence of rapamycin (Fig. 2B). A brief exposure to FMRFa depressed EPSP amplitudes to $58 \pm 5.9 \%$ at synapses expressing P-LTF $(N=6)$, which was not significantly different $(p>0.6)$ than a decline in amplitude to $64 \pm 5.5 \%$ at control synapses $(N=6)$ in the presence of rapamycin (Fig. 2B). As for changes evoked in the absence of rapamycin, the overall depression evoked by FMRFa at synapses expressing P-LTF resulted in synapse strength returning to the amplitude recorded on day 4 before the applications of 5-HT that evoked P-LTF $(103 \pm 5.7 \%)$. Individual group changes evoked by either 5-HT or FMRFa in the presence of rapamycin were not significantly different $(p>0.6$ or higher for both controls and those expressing P-LTF) than those evoked in the absence of rapamycin. Thus, protein synthesis is not required for the expression of short-term plasticity at synapses expressing persistent plasticity; post-translational modifications of existing 

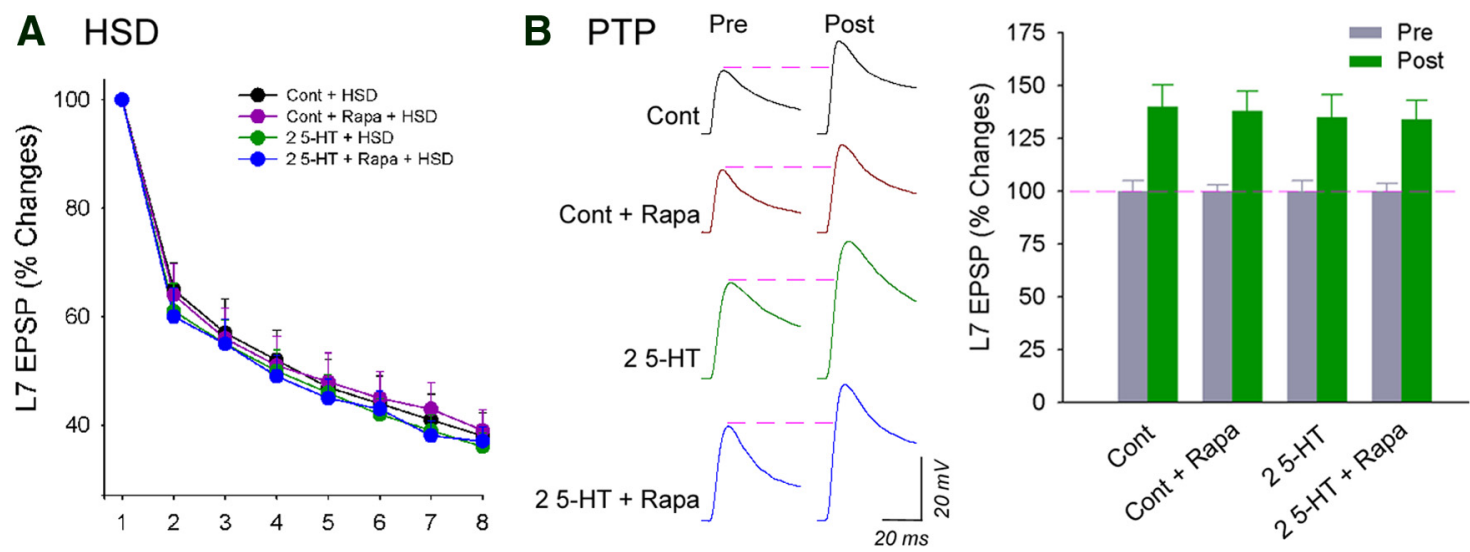

Figure 3. Persistent LTF did not affect the expression of short-term homosynaptic plasticity. $A$, Kinetics of HSD on day 7 in the absence or presence of rapamycin is not altered at the same synapses expressing persistent LTF. The first EPSP amplitude for all treatments was normalized as 100\%. By the eighth stimulus, EPSP amplitudes were depressed to $38 \%$ for all conditions. A two-factor ANOVA indicated no significant effect on the kinetics of HSD for each group ( $\mathrm{df}=18,216 ; F=0.520 ; p>0.9$ ), but a one-factor ANOVA shows a significant decline in EPSP amplitude for all treatments $(F=236.888, p<0.001)$. B, PTP was not affected by P-LTF expressed at the same synapses. Left, Sample traces of EPSPs evoked in L7 on day 7 before (Pre) and 1 min after (Post) tetanic stimulation in the absence or presence or rapamycin. A two-factor ANOVA indicated no significant effect on the expression of PTP for each group (df $=3,22 ; F=0.203 ; p>0.8$ ), but a one-factor ANOVA shows a significant increase in EPSP amplitude for each treatment $(F=144.274 ; p<0.001)$.

proteins continue to contribute to the expression of short-term plasticity.

Short-term homosynaptic plasticity was not affected when sensorimotor synapses express P-LTF (Fig. 3). With lowfrequency stimulation, the kinetics of HSD is unaffected when sensorimotor synapses express P-LTF (Fig. 3A). When normalized to the initial EPSP on day $7(100 \%)$, the decline in EPSP amplitude at synapses express P-LTF $(N=10)$ with each successive stimulus to the sensory neuron was a close match $(p>0.9)$ to the decline evoked in control synapses $(N=10)$. The presence of rapamycin did not alter the kinetics of HSD for synapses expressing P-LTF $(N=10)$ or controls $(N=10)$. By the last stimulus, EPSP amplitudes declined to $36 \pm 2.6 \%$ and $37 \pm$ $2.7 \%$ at synapses expressing P-LTF in the absence or presence of rapamycin, and declined to $38 \pm 4.3 \%$ and $39 \pm 3.9 \%$ at control synapses in the absence or presence of rapamycin (Fig. $3 A$ ). For synapses expressing P-LTF, the overall decline after the last stimulus was to $61 \pm 3.6 \%$ (absence of rapamycin) and $59 \pm 5.9 \%$ (presence of rapamycin) of the EPSP amplitude recorded on day 4 before the applications of 5-HT that evoked P-LTF. Thus, the expression of HSD is unaffected at synapses expressing P-LTF and, as at naive synapses, does not depend on protein synthesis.

Short-term homosynaptic facilitation was not affected by P-LTF in the absence or presence of rapamycin (Fig. 3B). Tetanic stimulation of the sensory neuron evoked an increase in EPSP amplitude of $135 \pm 10.6 \%(N=6)$ at sensorimotor synapses expressing P-LTF that was not significantly different $(p>0.8)$ than the increase of $140 \pm 10.5 \%(N=6)$ at control synapses. In the presence of rapamycin, titanic stimulation evoked comparable increases in EPSP amplitude: $134 \pm 8.9 \%$ at synapses expressing P-LTF $(N=7)$ compared with $138 \pm 9.4 \%$ at control synapses $(N=7)$. Thus, short-term homosynaptic plasticity (bidirectional changes in EPSP amplitude) does not appear to be altered by the expression of P-LTF. Short-term homosynaptic plasticity is independent of ongoing protein synthesis that may contribute to the persistent plasticity, but is dependent on any activity-dependent post-translational modifications of existing proteins.
Heterosynaptic, but not homosynaptic, activation in the presence of rapamycin rapidly reverses P-LTF

Short-term heterosynaptic or homosynaptic activation of sensorimotor synapses expressing P-LTF did not interfere with P-LTF (Figs. 4, 5). EPSPs were recorded on day 8 (and in some cases on day 9; data not shown), maintained a significant increase over controls, and were not significantly different from sensorimotor synapses expressing P-LTF that were not stimulated to express short-term plasticity on day 7 .

Following short-term facilitation evoked by a brief application of 5-HT (Fig. 4A), synapse strength on day 8 remained significantly elevated at synapses expressing P-LTF: $171 \pm 6.3 \%$ $(N=10)$ in cultures exposed to 5 -HT on day 7 (2 5-HT plus 5 -HT) compared with $168 \pm 7.4 \%$ in cultures treated with 2 5 -HT alone $(N=10)$ or $166 \pm 10.6 \%$ in cultures treated with 25 -HT plus vehicle on day $7(N=6)$. Control cultures exposed to a single brief application of 5-HT or vehicle on day 7 failed to show any significant change in EPSP amplitude on day 8: $96 \pm$ $3.6 \%(N=6)$ or $96 \pm 3.3 \%(N=6)$ compared with control ( $95 \pm$ $4.1 \% ; N=10$ ). Following short-term depression evoked by a brief application of FMRFa (Fig. 4B), synapse strength on day 8 also remained significantly elevated at synapses expressing P-LTF: $170 \pm 11.5 \%(N=12)$ in cultures exposed to FMRFa on day 7 (2 5-HT plus FMRFa) compared with $170 \pm 13.0 \%(N=$ $10)$ in cultures treated with 25 -HT alone or $167 \pm 10.4 \%$ in cultures treated with 25 -HT plus vehicle on day $7(N=6)$. Control cultures exposed to a single brief application of FMRFa or vehicle on day 7 failed to show a significant change in EPSP amplitude on day 8: $95 \pm 3.6 \%(N=6)$ or $96 \pm 3.3 \%(N=6)$ compared with control $(94 \pm 6.3 \% ; N=10)$. Thus, stimuli that evoke short-term heterosynaptic plasticity do not alter P-LTF.

Stimuli that evoked short-term homosynaptic plasticity also did not alter P-LTF (Fig. 5). Following HSD evoked by lowfrequency stimulation or PTP evoked by tetanus, synapse strength on day 8 remained significantly elevated at synapses expressing P-LTF: $164 \pm 8.2 \%(N=10)$ following HSD evoked on day 7 (2 5-HT plus HSD), $168 \pm 7.9 \%(N=10)$ following PTP evoked on day 7 (2 5-HT plus PTP) compared with $173 \pm 9.8$ (2 5-HT; $N=13$ ) at synapses receiving no stimuli on day 7 (Fig. 5). 
A

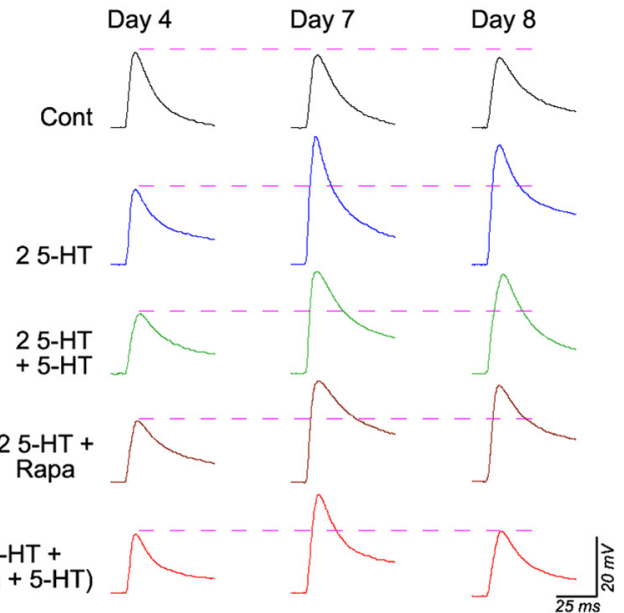

B

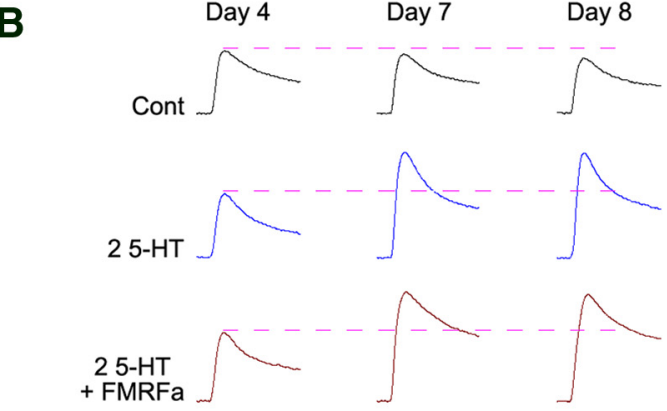

$\left.\begin{array}{c}25-\mathrm{HT}+ \\ (\mathrm{Rapa}+\mathrm{FMRFa})\end{array}\right]$
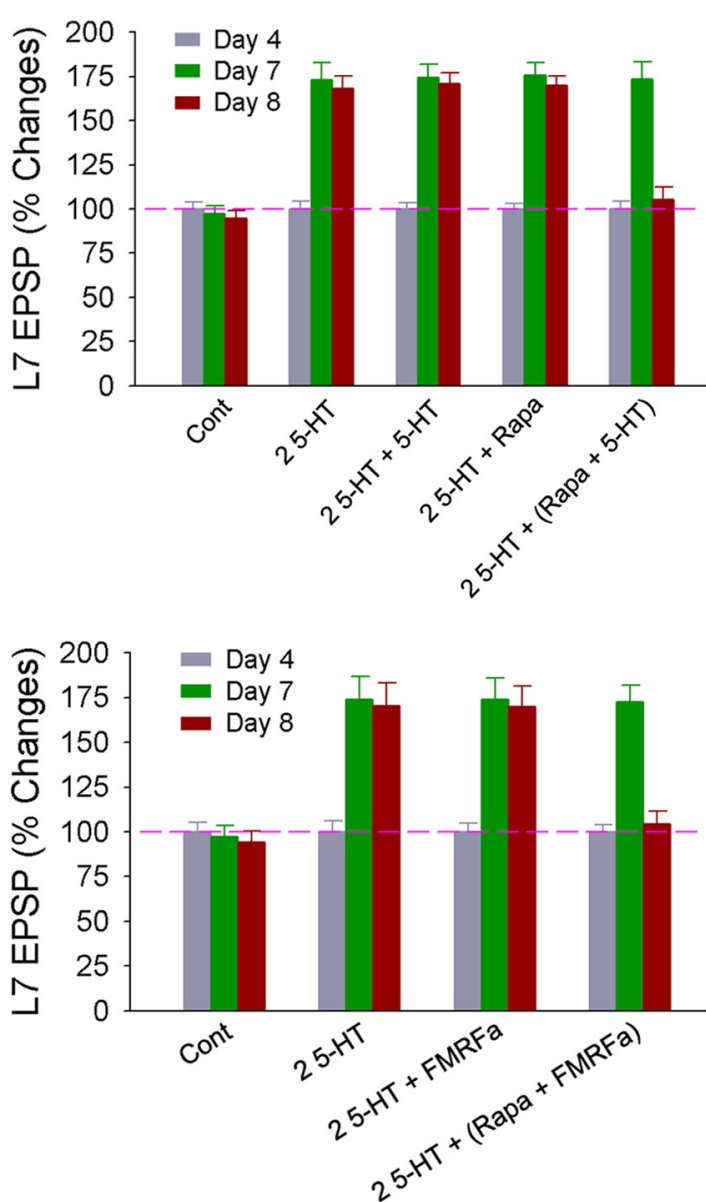

Figure 4. Persistent LTF was disrupted by short-term heterosynaptic plasticity only in the presence of rapamycin. A, Persistent LTF is reversed when short-term heterosynaptic plasticity is evoked by 5 -HT in the presence of rapamycin. Left, Traces of EPSPs evoked in L7 for different treatments on day 4 (baseline strength of synapses), day 7 (strength after control or 25-HT treatments and before brief application of $5-\mathrm{HT}$ in the absence or presence of rapamycin, or an application of rapamycin alone), and day 8 (strength after all day 7 treatments). Right, Summary of the changes in EPSP amplitudes over time for each condition. A two-factor ANOVA indicated a significant effect of treatments on the changes in EPSP over time (df $=8,94 ; F=81.957 ; p<0.001$ ). Individual group comparisons indicated a significant increase in EPSP amplitude over control on day 7 for all groups treated with 25 -HT ( $F$ values between 11.068 and $12.380 ; p<0.01$ ). 0 n day 8 , all groups treated with 25 -HT remained significantly higher than controls ( $F$ values between 16.668 and $18.340 ; p<0.01$ ) except for the group treated with a brief application of 5 -HT in the presence of rapamycin on day 7 [25-HT plus (rapamycin plus 5-HT)], which resulted in a change in EPSP amplitude that was no longer significantly different from controls $(F=0.351 ; p>0.05)$, but was significantly lower than those of 25-HT, 25-HT plus 5-HT, and 25-HT plus rapamycin (Fvalues between 12.860 and 14.296; $p<0.01$ ). B, Persistent LTF is reversed when short-term heterosynaptic plasticity is evoked by FMRFa in the presence of rapamycin. Left, Sample traces of EPSPs evoked in L7 for different treatments on day 4 (baseline strength of synapses), day 7 (strength after control or 25 -HT treatments and before a brief application of FMRFa in the absence or presence of rapamycin), and day 8 (strength after all day 7 treatments). Right, Summary of the changes in EPSP amplitudes over time for each condition. A two-factor ANOVA indicated a significant effect of treatments on the changes in EPSP over time ( $d f=6,80 ; F=50.906 ; p<0.001)$. Individual group comparisons indicated a significant increase in EPSP amplitude over control on day 7 for all groups treated with 25 -HT ( $F$ values between 7.889 and $8.393 ; p<0.01)$. On day 8 , all groups treated with 25 -HT remained significantly higher than control ( $F$ values between 9.000 and $9.667 ; p<0.01)$ except for the group treated with a brief application of FMRFa in the presence of rapamycin on day 7 [ 25 -HT plus (rapamycin plus $F M R F a)$ ], which resulted in a change in EPSP amplitude that was no longer significantly different from control $(F=0.174 ; p>0.05)$, but was significantly lower than those of 25 -HT and 25 -HT plus FMRFa $(F=7.378$ and $7.981 ; p<0.01)$.

HSD or PTP stimulation of control cultures on day 7 did not significantly affect synapse strength on day $8: 95 \pm 3.4 \%(N=6)$ or $94 \pm 4.4 \%(N=6)$ compared with control $(94 \pm 3.1 \% ; N=$ 10). Thus, exposure to short-term plasticity, even those that depress synapses to levels at or below the initial basal level of synapse strength, failed to alter P-LTF. The elevated synapse strength associated with P-LTF appears as a "new" baseline where synapse strength can be modulated up or down for short durations as in control naive synapses.

Short-term heterosynaptic activation of the sensorimotor synapses in the presence of rapamycin evoked a rapid reversal to basal levels at sensorimotor synapses expressing P-LTF (Fig. 4). Brief application of 5-HT on day 7 in the presence of rapamycin [2 5 -HT plus (rapamycin plus 5-HT); $N=11$ ] resulted in the failure to maintain P-LTF on day 8 (and day 9; data not shown).
EPSP amplitude was now comparable to controls $(N=10)$ : $105 \pm 7.1 \%$ compared with $95 \pm 4.1 \%$, respectively (Fig. $4 A$ ). Similarly, a brief application of FMRFa on day 7 in the presence of rapamycin [2 5-HT plus (rapamycin plus FMRFa); $N=12$ ] also resulted in the failure to maintain P-LTF on day 8 (and day 9; data not shown). EPSP amplitude was now comparable to controls $(N=10): 104 \pm 7.0 \%$ compared with $94 \pm 6.3 \%$, respectively (Fig. 4B). Application of rapamycin alone (2 5-HT plus rapamycin; $N=11)$ failed to alter P-LTF ( $170 \pm 5.5 \%$ on day 8 compared with $168 \pm 7.4 \%$ on day 8 for 25 -HT alone, $N=10$; Fig. $4 A$ ). In addition, evoking short-term heterosynaptic plasticity in the presence of rapamycin in control "naïve" sensorimotor synapses failed to alter synapse strength on day 8 [94 $\pm 3.1 \%$ in control cultures treated with a brief of 5-HT $(N=6)$ compared with $95 \pm$ $4.1 \%$ in control alone; $95 \pm 4.0 \%$ in control cultures treated with 


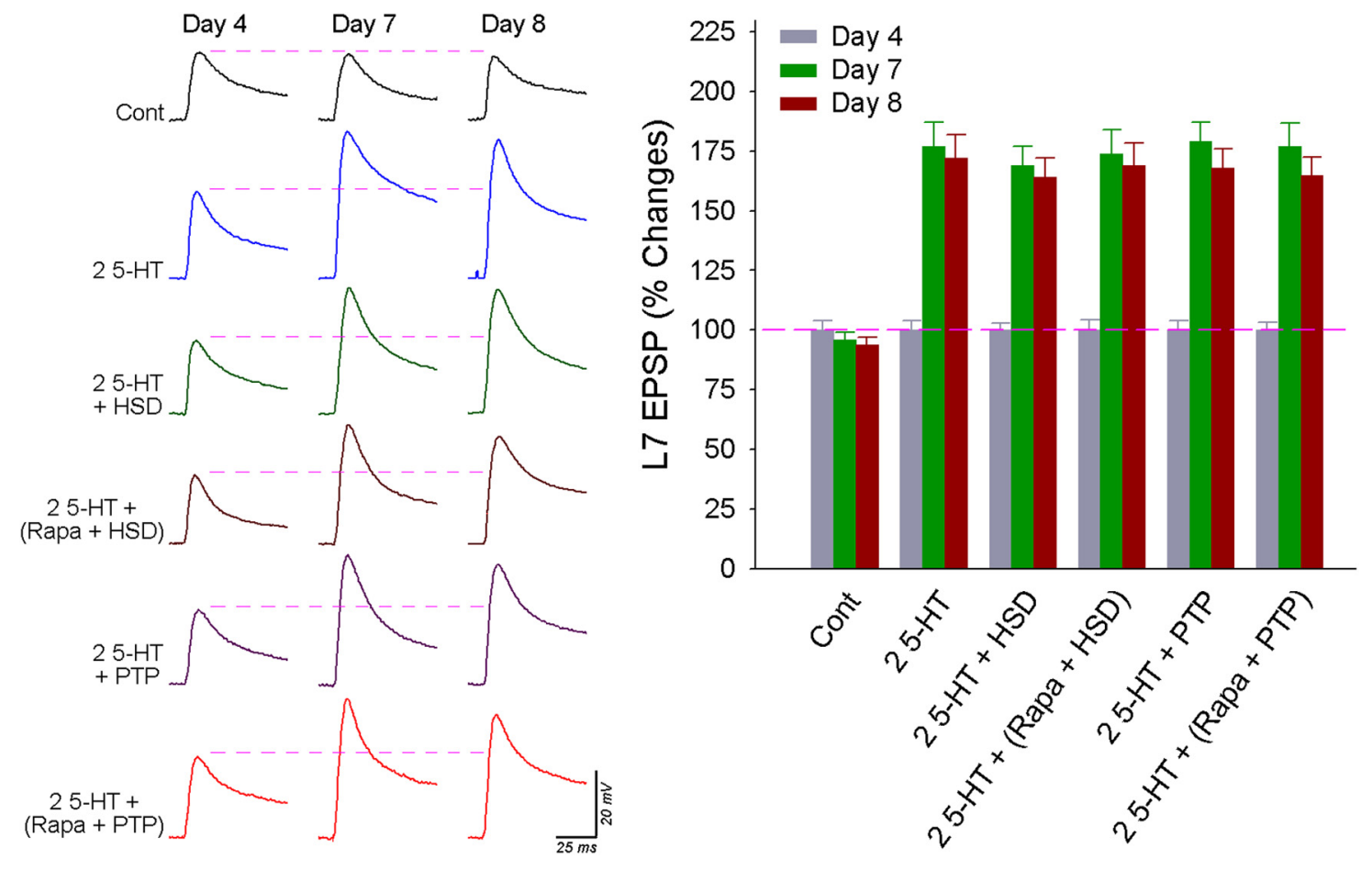

Figure 5. Persistent LTF was not disrupted by homosynaptic plasticity either in the absence or presence of rapamycin. Left, Sample traces of EPSPs evoked in L7 for different treatments on day 4 (baseline strength of synapses), day 7 (strength after control or 25-HT treatments and before HSD or PTP in the absence or presence of rapamycin), and day 8 (strength after all day 7 treatments). HSD or PTP evoked in the absence or presence of rapamycin did not affect P-LTF produced by $25-$ HT. Right, Summary of the changes in EPSP amplitudes over time for each condition. A two-factor ANOVA indicated a significant effect of treatments on changes in EPSP amplitude over time ( $\mathrm{df}=10,122 ; F=25.867 ; p<0.001)$. Individual group comparisons indicated a significant increase in EPSP amplitude over controls on day 7 for all groups treated with $25-\mathrm{HT}$ (values of $\mathrm{F}$ between 5.993 and $8.365 ; p<0.01$ ), and on day 8 for all groups treated with 25 -HT ( $F$ values between 6.509 and $9.215 ; p<0.01$ ) including those treated with homosynaptic stimulation plus rapamycin on day 7.

a brief application of FMRFa $(N=6)$ compared with $94 \pm 6.3 \%$ in control alone]. Thus, heterosynaptic activation of sensorimotor synapses (evoking bidirectional changes in synapse strength) expressing persistent plasticity results in a labile state where the presence of a protein synthesis inhibitor leads to a rapid reversal in persistent long-term plasticity.

Homosynaptic activation of the sensorimotor synapses in the presence of rapamycin failed to evoke a significant change in synapse strength at sensorimotor synapses expressing P-LTF (Fig. 5). HSD $(N=11)$ or PTP $(N=13)$ evoked on day 7 in the presence of rapamycin did not significantly affect the enhanced EPSP amplitudes on day 8 at synapses expressing P-LTF: $169 \pm$ 9.5\% after HSD [2 5-HT plus (rapamycin plus HSD)] and $165 \pm$ 7.5\% after PTP [2 5-HT plus (rapamycin plus PTP)]. The P-LTF expressed at these synapses was not significantly different from the P-LTF expressed at synapses exposed to HSD (164 $\pm 8.2 \%$; $N=10)$ or PTP $(168 \pm 7.9 \% ; N=10)$ on day 7 in the absence of rapamycin or the P-LTF expressed when no activity was presented on day $7(173 \pm 9.8 \% ; N=13)$. We also found that homosynaptic activation in the presence of anisomycin, a general inhibitor of protein synthesis, also failed to reverse P-LTF. Following HSD or PTP on day 7, EPSP amplitudes remained significantly elevated on day 8: $163 \pm 11.6 \%(N=8)$ for PTP and $167 \pm 8.4 \%$ for HSD $(N=9)$ compared with $95 \pm 3.3 \%$ for controls $(N=7)$. Thus, for a nonassociative form of P-LTF (evoked by repeated applications of 5-HT presented over $2 \mathrm{~d}$ ), homosynaptic activation of the synapse failed to evoke a labile state in synapses expressing persistent plasticity when the homosynaptic stimuli are presented in the presence of protein synthesis inhibitors.

\section{Discussion}

Aplysia sensorimotor synapses can express both nonassociative P-LTF and different forms of short-term plasticity (STP) that are functionally indistinguishable from STP evoked at naive synapses. Even short-term depression that reduced synapse strength to levels at or below levels detected before the initial stimuli did not disrupt P-LTF. Thus, the synapse strength associated with persistent plasticity appears to represent a new baseline that can be modulated bidirectionally to allow the neural circuit to respond appropriately to subsequent stimuli.

However, this new baseline differs from the control baseline in that the "added" strength of the synapse becomes labile when selective forms of neuron-synapse stimulation-heterosynaptic plasticity - are paired with rapamycin. Reconsolidation of stored memories and synaptic plasticity are sensitive to disruption by the timely presence of rapamycin or other inhibitors (Nader et al., 2000; Doyère et al., 2007; Gafford et al., 2011; Stoica et al., 2011; Jobim et al., 2012; Barak et al., 2013; Li et al., 2013). Generally, the labile nature is expressed in appropriate CNS regions and circuits that participated in the initial learning and with specific external stimuli that reactivate the initial memory. However, these studies could not determine whether the same synapses encoding the initial memory trace are also undergoing reversals in their cellular properties, and the types of stimuli at the reactivated synapses that evoke the labile state. Our results indicate that the labile state in sensorimotor synapses expressing added strength is evoked selectively with modulatory heterosynaptic stimuli including one that evokes plasticity in the opposite direction. Thus, sensorimotor synapses expressing nonassociative P-LTF 
are made labile selectively when neuromodulator-induced plasticity is paired with the timely interference of protein synthesis and reverses P-LTF.

\section{Short-term and persistent synaptic plasticity are coexpressed}

Both homosynaptic and heterosynaptic STP are expressed at synapses expressing P-LTF without any apparent attenuation. Since the stimuli inducing STP activate different cellular/molecular mechanisms, our results suggest that synapses expressing P-LTF retain the same molecular machinery as naive synapses in expressing short-term, activity-dependent plasticity.

Changes in both the number (Bailey and Chen, 1988; Glanzman et al., 1990; Bailey et al., 1992; O'Leary et al., 1995) and function (Frost et al., 1985; Kim et al., 2003; Miniaci et al., 2008; Hu et al., 2011; Liu et al., 2013) of sensorimotor synapses contribute to P-LTF. The functional changes include a reduction in silent synapses and an increase in miniature EPSP (mEPSP) frequency (Dale et al., 1988; Kim et al., 2003; Jin et al., 2012). HSD is primarily produced by a reduction in release probability and a disruption of excitation-secretion coupling at presynaptic varicosities, resulting in the silencing of release sites with low release probability (Eliot et al., 1994; Armitage and Siegelbaum, 1998; Royer et al., 2000; Gover et al., 2002; Zhao and Klein, 2002; Malkinson and Spira, 2013). Thus, it was somewhat surprising that the kinetics of HSD was unaffected at synapses expressing P-LTF, where release probability and mEPSP frequency are high. The overall properties of release sites at sensorimotor synapses expressing P-LTF are similar to those of naive synapses. This is consistent with the findings that the kinetics of HSD is independent of the initial strength of sensorimotor synapse (Montarolo et al., 1986; Sun and Schacher, 1996). The cellular/molecular mechanisms for maintaining nonassociative P-LTF do not disrupt the cellular/molecular changes mediating HSD.

The tetanus that evokes PTP at sensorimotor synapses of $A p$ lysia activates both presynaptic and postsynaptic mechanisms: the release of calcium from internal stores, the activation of CaMK and MAPK, and calcium-dependent protein degradation (Schaffhausen et al., 2001; Jin and Hawkins, 2003; Khoutorsky and Spira, 2009). The activation of MAPK also contributes to LTF at sensorimotor synapses and may contribute to P-LTF (Martin et al., 1997; Purcell et al., 2003; Hu et al., 2004, 2011). In addition, activity-dependent potentiation is typically attenuated at synapses recently potentiated by previous stimuli (Montgomery and Madison, 2004). Thus, it was surprising that PTP at synapses expressing P-LTF was evoked without apparent attenuation. However, previous studies generally examined the consequences of additional stimuli soon after the induction of activitydependent long-term plasticity. The plasticity induced by the prior stimulation may not have reached the "maintenance" phase of persistent plasticity. Our results suggest that synapses maintaining P-LTF can undergo additional potentiation that is functionally equivalent to PTP expressed at naive synapses.

Synapses expressing P-LTF also express heterosynaptic STP that is functionally equivalent to that expressed at naive synapses. A brief application of 5-HT leads to the activation of kinases in sensory neurons (PKA and PKC) that phosphorylate pre-existing substrates leading to changes in action potential shape and the upregulation of vesicle mobilization (Brunelli et al., 1976; Castellucci et al., 1980; Hochner et al., 1986; Ocorr et al., 1986; Sacktor et al., 1988; Braha et al., 1990; Ghirardi et al., 1992; Sugita et al., 1992; Klein, 1993; Byrne and Kandel, 1996). 5-HT also activates responses and signaling pathways in the postsynaptic motor neuron (Cleary et al., 1998; Li et al., 2005; Villareal et al., 2007; Fulton et al., 2008). In contrast, FMRFa evokes synaptic depression by activating p38 MAPK and phosphatases that lead to posttranslational modifications in pre-existing substrates that produce spike narrowing and a decline in release probabilities from the sensory neuron release sites (Belardetti et al., 1987; Piomelli et al., 1987; Sweatt et al., 1989; Dale and Kandel, 1990; Pieroni and Byrne, 1992; Small et al., 1992; Endo et al., 1995; Guan et al., 2003). FMRFa evokes responses in the motor neuron (Ruben et al., 1986; Sossin et al., 1987; Pieroni and Byrne, 1992; Belkin and Abrams, 1993; Wu and Schacher, 1994; Xu et al., 1994; Lin and Glanzman, 1996), suggesting that FMRFa activates signaling pathways in the postsynaptic neuron. Our results suggest that similar post-translational modifications are evoked by the stimuli at the sensorimotor synapse expressing nonassociative P-LTF as at naive synapses.

\section{Heterosynaptic plasticity selectively evokes a labile state at synapses expressing P-LTF}

Do 5-HT and FMRFa activate the same signaling cascades in the sensory neuron and L7 when the synapses express P-LTF? Even if the same pathways are activated, do heterosynaptic stimuli lead to modifications of the same substrates in neurons expressing P-LTF as the substrates modified in naive synapses? Molecular changes in the circuit evoked by stimuli that produce persistent plasticity are likely to provide a different group of potential substrates for modification by subsequent heterosynaptic stimuli (Hu et al., 2011). Persistent plasticity requires persistent changes in proteins levels (Miniaci et al., 2008; Si et al., 2010; Pavlopoulos et al., 2011), in the activation of kinases (Sacktor, 2011; Lisman et al., 2012), in the expression/activation of transcription factors (Barco et al., 2002, 2005; Liu et al., 2008, 2011), and in epigenetic changes affecting chromatin organization and activation of gene expression (Rajasethupathy et al., 2009, 2012; Feng et al., 2010), thereby altering overall levels of mRNA and protein expression. Thus, new levels of expression of pre-existing substrates and of novel substrates associated with P-LTF could be subject to posttranslational modifications when 5-HT or FMRFa evoke STP. Despite these potential differences, P-LTF and STP were unaffected when the two forms of plasticity interacted with each other.

The labile nature of some stimuli, heterosynaptic but not homosynaptic, were revealed when the stimuli were presented in the presence of a protein synthesis inhibitor such as rapamycin. Rapamycin alone failed to induce a labile state and interfere with P-LTF (Hu et al., 2011; Fig. 4). Lee et al. (2012) reported that the action potential activity of sensory neurons in the presence of a protein synthesis inhibitor also induced a labile state at sensorimotor synapses. The apparent discrepancy with our results may be accounted for by differences in protocol. First, they induced LTF with $1 \mathrm{~d}$ of 5-HT applications at concentrations much higher than used here. Second, they used a stimulation protocol of firing a single action potential in sensory neurons at $1 \mathrm{~min}$ intervals $(4 \times)$ that does not evoke any significant plasticity. Third, they stimulated $24 \mathrm{~h}$ after termination of the 5-HT applications, which is during the consolidation phase of LTF (Miniaci et al., 2008; Liu et al., 2011). Fourth, they used a powerful protein synthesis inhibitor (100 $\mu \mathrm{M}$ emetine) that is only partially reversible. When neurons and synapses express a more consolidated form of P-LTF, they shed the increase in synaptic strength and return to levels of synaptic strength expressed before 5-HT stimulation only when heterosynaptic stimuli are presented in the presence of rapamycin, while naive synapses treated the same way retain their initial baseline levels of synaptic strength. 
What is the nature of the labile state when heterosynaptic stimuli are paired with rapamycin? One possibility is that these stimuli selectively lead to the phosphorylation or dephosphorylation of specific proteins in sensory neurons and/or motor neurons that participate in the maintenance of the plasticity. These post-translational changes might lead to added degradation of the modified proteins or of other proteins associated with maintaining P-LTF, which cannot be replenished in a timely manner when protein synthesis is inhibited by rapamycin. The ubiquitinproteasome pathways contribute significantly to long-term plasticity and reconsolidation (Chain et al., 1999b; Karpova et al., 2006; Dong et al., 2008; Fioravante et al., 2008; Lee et al., 2008; Citri et al., 2009; Kaang and Choi, 2011; Da Silva et al., 2013). Stimuli that evoke long-term plasticity in Aplysia activate this degradation pathway, which may persist long after the induction of the synaptic changes (Chain et al., 1995, 1999a; Hegde et al., 1997; Lee et al., 2012). Brief exposure to 5-HT or FMRFa, but not to stimuli that evoke HSD or PTP, may induce a reactivation of this pathway when the neurons express P-LTF (Zhao et al., 2003; Upadhya et al., 2006; Lee et al., 2012). The identity of the key substrates in sensory and/or motor neurons influenced selectively by both the neuromodulators and rapamycin and the role of protein degradation that may contribute to the labile state and reversal of P-LTF await further study.

\section{References}

Armitage BA, Siegelbaum SA (1998) Presynaptic induction and expression of homosynaptic depression at Aplysia sensorimotor neuron synapses. J Neurosci 18:8770-8779. Medline

Bailey CH, Chen A (1988) Long-term sensitization in Aplysia increases the number of presynaptic contacts onto the identified gill motor neuron L7. Proc Natl Acad Sci U S A 85:9355-9359. Medline

Bailey CH, Montarolo P, Chen M, Kandel ER, Schacher S (1992) Inhibitors of protein and RNA synthesis block structural changes that accompany long-term heterosynaptic plasticity in Aplysia. Neuron 9:749-758. CrossRef Medline

Barak S, Liu F, Ben Hamida S, Yowell QV, Neasta J, Kharazia V, Janak PH, Ron D (2013) Disruption of alchohol-related memories by mTORC1 inhibition prevents relapse. Nat Neurosci 16:1111-1117. CrossRef Medline

Barco A, Alarcon JM, Kandel ER (2002) Expression of constitutively active CREB protein facilitates the late phase of long-term potentiation by enhancing synaptic capture. Cell 108:689-703. CrossRef Medline

Barco A, Patterson SL, Patterson S, Alarcon JM, Gromova P, Mata-Roig M, Morozov A, Kandel ER (2005) Gene expression profiling of facilitated L-LTP in VP16-CREB mice reveals that BDNF is critical for the maintenance of LTP and its synaptic capture. Neuron 48:123-137. CrossRef Medline

Belardetti F, Kandel ER, Siegelbaum SA (1987) Neuronal inhibition by the peptide FMRFamide involves opening of S K+ channels. Nature 325: 153-156. CrossRef Medline

Belkin KJ, Abrams TW (1993) FMRFamide produces biphasic modulation of the LFS motor neurons in the neural circuit of the sophone withdrawal reflex of Aplysia by activating NA+ and K+ currents. J Neurosci 13: 5139-5152. Medline

Boccia M, Freudenthal R, Blake M, de la Fuente V, Acosta G, Baratti C, Romano A (2007) Activation of hippocampal nuclear factor- $\kappa$ B by retrieval is required for memory reconsolidation. J Neurosci 27:1343613445. CrossRef Medline

Braha O, Dale N, Hochner B, Klein M, Abrams TW, Kandel ER (1990) Second messengers involved in the two processes of presynaptic facilitation that contribute to sensitization and dishabituation in Aplysia sensory neurons. Proc Natl Acad Sci U S A 87:2040-2044. CrossRef Medline

Brunelli M, Castellucci V, Kandel ER (1976) Synaptic facilitation and behavioral sensitization in Aplysia: posslible role of serotonin and cyclic AMP. Science 194:1178-1181. CrossRef Medline

Byrne JH, Kandel ER (1996) Presynaptic facilitation revisited: state and time dependence. J Neurosci 16:425-435. Medline
Cai D, Chen S, Glanzman DL (2008) Postsynaptic regulation of long-term facilitation in Aplysia. Curr Biol 18:920-925. CrossRef Medline

Cai D, Pearce K, Chen S, Glanzman DL (2012) Reconsolidation of longterm memory in Aplysia. Curr Biol 22:1783-1788. CrossRef Medline

Castellucci VF, Carew TJ, Kandel ER (1978) Cellular analysis of long-term habituation of the gill-withdrawal reflex of Aplysia californica. Science 202:1306-1308. CrossRef Medline

Castellucci VF, Kandel ER, Schwartz JH, Wilson FD, Nairn AC, Greengard P (1980) Intracellular injection of the catalytic subunit of cyclic AMPdependent protein kinase simulates facilitation of tramsitter release underlying behavior sensitization in Aplysia. Proc Natl Acad Sci U S A 77: 7492-7496. CrossRef Medline

Chain DG, Hegde AN, Yamamoto N, Liu-Marsh B, SchwartzJH (1995) Persistent activation of cAMP-dependent protein kinase by regulated proteolysis suggests a neuron-specific function of the ubiquitin system in Aplysia. J Neurosci 15:7592-7603. Medline

Chain DG, Casadio A, Schacher S, Hegde AN, Valbrun M, Yamamoto N, Goldberg AL, Bartsch D, Kandel ER, Schwartz JH (1999a) Mechanisms for generating the autonomous cAMP-dependent protein kinase required for long-term facilitation in Aplysia. Neuron 22:147-156. CrossRef Medline

Chain DG, Schwartz JH, Hegde AN (1999b) Ubiquitin-mediated proteolysis in learning and memory. Mol Neurobiol 20:125-142. CrossRef Medline

Choi YB, Li HL, Kassabov SR, Jin I, Puthanveettil SV, Karl KA, Lu Y, Kim JH, Bailey CH, Kandel ER (2011) Neurexin-neuroligin transsynaptic interaction mediates learning-related synaptic remodeling and long-term facilitation in Aplysia. Neuron 70:468-481. CrossRef Medline

Citri A, Soler-Llavina G, Bhattacharyya S, Malenka RC (2009) NMDA receptor- and metabotropic glutamate receptor-dependent long-term depression are differentially regulated by the ubiquitin-proteasome system. Eur J Neurosci 30:1443-1450. CrossRef Medline

Cleary LJ, Lee WL, Byrne JH (1998) Cellular correlates of long-term sensitization in Aplysia. J Neurosci 18:5988-5998. Medline

Dale N, Kandel ER (1990) Facilitatory and inhibitory transmitters modulate spontaneous transmitter release at cultured Aplysia sensorimotor synapses. J Physiol 421:203-222. Medline

Dale N, Schacher S, Kandel ER (1988) Long-term facilitation in Aplysia involves increase in transmitter release. Science 239:282-285. CrossRef Medline

Da Silva WC, Cardoso G, Bonini JS, Benetti F, Izquierdo I (2013) Memory reconsolidation and its maintenance depend on L-voltage-dependent calcium channels and CaMKII functions regulating protein turnover in the hippocampus. Proc Natl Acad Sci U S A 110:6566-6570. CrossRef Medline

Dong C, Upadhya SC, Ding L, Smith TK, Hegde AN (2008) Proteasome inhibition enhances the inducation and impairs the maintenance of longpahse long-term potentiation. Learn Mem 15:335-347. CrossRef Medline

Doyère V, Debiec J, Monfils MH, Schafe GE, LeDoux JE (2007) Synapsespecific reconsolidation of distinct fear memories in the lateral amygdala. Nat Neurosci 10:414-416. CrossRef Medline

Duvarci S, Nader K (2004) Characterization of fear memory reconsolidation. J Neurosci 24:9269-9275. CrossRef Medline

Eliot LS, Kandel ER, Hawkins RD (1994) Modulation of spontaneous transmitter release during depression and posttetanic potentiation of Aplysia sensory-motor neuron synapses isolated in culture. J Neurosci 14:3280 3292. Medline

Endo S, Critz SD, Byrne JH, Shenolikar S (1995) Protein phosphatase-1 regulates outward $\mathrm{K}+$ currents in sensory neurons of Aplysia californica. J Neurochem 64:1833-1840. Medline

Feng J, Zhou Y, Campbell SL, Le T, Li E, Sweatt JD, Silva AJ, Fan G (2010) Dnmt1 and Dnmt3a maintain DNA methylation and regulate synap[tic function in adult forebrain neurons. Nat Neurosci 13:423-430. CrossRef Medline

Fioravante D, Liu RY, Byrne JH (2008) The ubiquitin-proteasome system is necessary for long-term synaptic depression in Aplysia. J Neurosci 28: 10245-10256. CrossRef Medline

Frost WN, Castellucci VF, Hawkins RD, Kandel ER (1985) Monosynaptic connections made by the sensory neurons of the gill- and siphon withdrawal reflex in Aplysia participate in the storage of long-term memory for sensitization. Proc Natl Acad Sci U S A 82:8266-8299. CrossRef Medline 
Fulton D, Condro MC, Pearce K, Glanzman DL (2008) The potential role of postsynaptic phospholipase $\mathrm{C}$ activity in synaptic facilitation and behavioral sensitization in Aplysia. J Neurophysiol 100:108-116. CrossRef Medline

Gafford GM, Parsons RG, Helmstetter FJ (2011) Consolidation and reconsolidation of contextual fear memory required mammalian target of rapamycin-dependent translation in the dorsal hippocampus. Neuroscience 182:98-104. CrossRef Medline

Ghirardi M, Braha O, Hochner B, Montarolo PG, Kandel ER, Dale N (1992) Roles of PKA and PKC in facilitation of evoked and spontaneous transmitter release at depressed and nondepressed synapses in Aplysia sensory neurons. Neuron 9:479-489. CrossRef Medline

Glanzman DL, Kandel ER, Schacher S (1990) Target-dependent structural changes accompanying long-term synaptic facilitation in Aplysia neurons. Science 249:799-802. CrossRef Medline

Gover TD, Jiang XY, Abrams TW (2002) Persistent, exocytosis-independent silencing of release sites underlies homosynaptic depression at sensory synapses in Aplysia. J Neurosci 22:1942-1955. Medline

Guan Z, Kim JH, Lomvardas S, Holick K, Xu S, Kandel ER, Schwartz JH (2003) p38 MAP kinase mediates both short-term and long-term synaptic depression in Aplysia. J Neurosci 23:7317-7325. Medline

Hatada Y, Wu F, Sun ZY, Schacher S, Goldberg DJ (2000) Presynaptic morphological changes associated with long-term synaptic facilitation are triggered by acting polymerization at preexisting varicosities. J Neurosci 20:RC82. Medline

Hegde AN, Inokuchi K, Pei W, Casadio A, Ghirardi M, Chain DG, Martin KC, Kandel ER, Schwartz JH (1997) Ubiquitin C-terminal hydrolase is an immediate-early gene essential for long-term facilitation in Aplysia. Cell 89:115-126. CrossRef Medline

Hochner B, Klein M, Schacher S, Kandel ER (1986) Additional component in the cellular mechanism of presynaptic facilitation contributes to behavioral dishabituation in Aplysia. Proc Natl Acad Sci U S A 83:8794-8798. CrossRef Medline

Hu JY, Glickman L, Wu F, Schacher S (2004) Serotonin regulates the secretion and autocrine action of a neuropeptide to activate MAPK required for long-term facilitation in Aplysia. Neuron 43:373-385. CrossRef Medline

Hu JY, Baussi O, Levine A, Chen Y, Schacher S (2011) Persistent long-term synaptic plasticity requires activation of a new signaling pathway by additional stimuli. J Neurosci 31:8841-8850. CrossRef Medline

Inda MC, Muravieva EV, Alberini CM (2011) Memory retrieval and the passage of time: from reconsolidation and strengthening to extinction. J Neurosci 31:1635-1643. CrossRef Medline

Jin I, Hawkins RD (2003) Presynaptic and postsynaptic mechanisms of a novel form of homosynaptic potentiation at Aplysia sensorimotor synapses. J Neurosci 23:7288-7297. Medline

Jin I, Udo H, Rayman JB, Puthanveettil S, Kandel ER, Hawkins RD (2012) Spontaneous transmitter release recruits postsynaptic mechanisms of long-term and intermediate-term facilitation in Aplysia. Proc Natl Acad Sci U S A 109:9137-9142. CrossRef Medline

Jobim PF, Pedroso TR, Christoff RR, Werenicz A, Maurmann N, Reolon GK, Roesler R (2012) Inhibition of mTOR by rapamycin in the amygdala or hippocampus impairs formation and reconsolidation of inhibitory avoidance memory. Neurobiol Learn Mem 97:105-112. CrossRef Medline

Kaang BK, Choi JH (2011) Protein degradation during reconsolidation as a mechanism for memory reorganization. Front Behav Neurosci 5:2. CrossRef Medline

Kandel ER (2001) The molecular biology of memory storage: a dialogue between genes and synapses. Science 294:1030-1038. CrossRef Medline

Karpova A, Mikhaylova M, Thomas U, Knöpfel T, Behnisch T (2006) Involvement of protein synthesis and degradation in long-term potentiation of Schaffer collateral CA1 synapses. J Neurosci 26:4949-4955. CrossRef Medline

Kelly A, Laroche S, Davis S (2003) Activation of mitogen-activated protein kinase/extracellular signal-regulated kinase in hippocampal circuitry is required for consolidation and reconsolidation of recognition memory. J Neurosci 23:5354-5360. Medline

Khoutorsky A, Spira ME (2009) Activity-dependent calpain activation plays a critical role in synaptic facilitation and post-tetanic potentiation. Learn Mem 16:129-141. CrossRef Medline

Kim JH, Udo H, Li HL, Youn TY, Chen M, Kandel ER, Bailey CH (2003) Presynaptic activation of silent synapses and growth of new synapses contribute to intermediate and long-term facilitation in Aplysia. Neuron 40:151-165. CrossRef Medline

Klein M (1993) Differential cyclic AMP dependence of facilitation at Aplysia sensorimotor synapses as a function of prior stimulation: augmentation versus restoration of transmitter release. J Neurosci 13:3793-3801. Medline

Lee SH, Choi JH, Lee N, Lee HR, Kim JI, Yu NK, Choi SL, Lee SH, Kim H, Kaang BK (2008) Synaptic protein degradation underlies destabilization of retrieved fear memory. Science 319:1253-1256. CrossRef Medline

Lee SH, Kwak C, Shim J, Kim JE, Choi SL, Kim HF, Jang DJ, Lee JA, Lee K, Lee CH, Lee YD, Miniaci MC, Bailey CH, Kandel ER, Kaang BK (2012) A cellular model of memory reconsolidation involves reactivation-induced destabilization and restabilization at the sensorimotor synapse in Aplysia. Proc Natl Acad Sci U S A 109:14200-14205. CrossRef Medline

Li Q, Roberts AC, Glanzman DL (2005) Synaptic facilitation and behavioral dishabituation in Aplysia: dependence on release of $\mathrm{Ca}^{2+}$ from postsynaptic intracellular stores, postsynaptic exocytosis, and modulation of postsynaptic AMPA receptor efficacy. J Neurosci 25:5623-5637. CrossRef Medline

Li Y, Meloni EG, Carlezon WA Jr, Milad MR, Pitman RK, Nader K, Bolshakov VY (2013) Learning and reconsolidation implicate different synaptic mechanisms. Proc Natl Acad Sci U S A 110:4798-4803. CrossRef Medline

Lin XY, Glanzman DL (1996) Long-term depression of Aplysia sensorimotor synapses in cell culture: inductive role of a rise in postsynaptic calcium. J Neurophysiol 76:2111-2114. Medline

Lisman J, Yasuda R, Raghavachari S (2012) Mechanisms of CaMKII action in long-term potentiation. Nat Rev Neurosci 13:169-182. Medline

Liu RY, Fioravante D, Shah S, Byrne JH (2008) cAMP response elementbinding protein 1 feed back loop is necessary for consolidation of longterm synaptic facilitation in Aplysia. J Neurosci 28:1970-1976. CrossRef Medline

Liu RY, Cleary LJ, Byrne JH (2011) The requirement for enhanced CREB1 expression in consolidation of long-term synaptic facilitation and longterm excitability in sensory neurons of Aplysia. J Neurosci 31:6871-6879. CrossRef Medline

Liu RY, Zhang Y, Baxter DA, Smolen P, Cleary LJ, Byrne JH (2013) Deficit in long-term synaptic plasticity is rescued by a computationally predicted stimulus protocol. J Neurosci 33:6944-6949. CrossRef Medline

Lubin FD, Sweatt JD (2007) The IkappaB kinase regulates chromatin structure during reconsolidation of conditioned fear memories. Neuron 55: 942-957. CrossRef Medline

Malkinson G, Spira ME (2013) Release properties of individual presynaptic boutons expressed during homosynaptic depression and heterosynaptic facilitation of the Aplysia sensorimotor synapse. Front Cell Neurosci 7:165. CrossRef Medline

Martin KC, Michael D, Rose JC, Barad M, Casadio A, Zhu H, Kandel ER (1997) MAP kinase translocates into the nucleus of the presynaptic cell and is required for long-term facilitation in Aplysia. Neuron 18:899-912. CrossRef Medline

Mauelshagen J, Parker GR, Carew TJ (1996) Dynamics of induction and expression of long-term synaptic facilitation in Aplysia. J Neurosci 16: 7099-7108. Medline

Mauelshagen J, Sherff CM, Carew TJ (1998) Differential induction of longterm synaptic facilitation by spaced and massed applications of serotonin at sensory neurons synapses of Aplysia californica. Learn Mem 5:246256. Medline

McGaugh JL (2000) Memory-a century of consolidation. Science 287: 248-251. CrossRef Medline

Miniaci MC, Kim JH, Puthanveettil SV, Si K, Zhu H, Kandel ER, Bailey CH (2008) Sustained CPEB-dependent local protein synthesis is required to stabilize synaptic growth for persistence of long-term facilitation in Aplysia. Neuron 59:1024-1036. CrossRef Medline

Montarolo PG, Goelet P, Castellucci VF, Morgan J, Kandel ER, Schacher S (1986) A critical period for macromolecular synthesis in long-term heterosynaptic facilitation in Aplysia. Science 234:1249-1254. CrossRef Medline

Montarolo PG, Kandel ER, Schacher S (1988) Long-term heterosynaptic inhibition in Aplysia. Nature 333:171-174. CrossRef Medline

Montgomery JM, Madison DV (2004) Discrete synaptic states define a major mechanism of synapse plasticity. Trends Neurosci 27:744-750. CrossRef Medline 
Morris RG, Inglis J, Ainge JA, Olverman HJ, Tulloch J, Dudai Y, Kelly PA (2006) Memory reconsolidation: sensitivity of spatial memory to inhibition of protein synthesis in dorsal hippocampus during encoding and retrieval. Neuron 50:479-489. CrossRef Medline

Nader K, Schafe GE, Le Doux JE (2000) Fear memories require protein synthesis in the amygdala for reconsolidation after retrieval. Nature 406: 722-726. CrossRef Medline

Ocorr KA, Tabata M, Byrne JH (1986) Stimuli that produce sensitization lead to elevation of cyclic AMP levels in tail sensory neurons of Aplysia. Brain Res 37:190-192. CrossRef Medline

O'Leary FA, Byrne JH, Cleary LJ (1995) Long-term structural remodeling in Aplysia sensory neurons required de novo protein synthesis during a critical time period. J Neurosci 15:3519-3525. Medline

Pavlopoulos E, Trifilieff P, Chevaleyre V, Fioriti L, Zairis S, Pagano A, Malleret G, Kandel ER (2011) Neuralized1 activates CPEB3: a function of nonproteolytic ubiquitin in synaptic plasticity and memory storage. Cell 147:1369-1383. CrossRef Medline

Pieroni JP, Byrne JH (1992) Differential effects of serotonin, FMRFamide, and small cardioactive peptide on multiple, distributed processes modulating sensorimotor synaptic transmission in Aplysia. J Neurosci 12:26332647. Medline

Pinsker HM, Hening WA, Carew TJ, Kandel ER (1973) Long-term sensitization of a defensive withdrawal reflex in Aplysia. Science 182:1039-1042. CrossRef Medline

Piomelli D, Volterra A, Dale N, Siegelbaum SA, Kandel ER, Schwartz JH, Belardetti F (1987) Lipoxygenase metabolites of arachidonic acid as second messesngers for presynaptic inhibition of Aplysia sensory cells. Nature 328:38-43. CrossRef Medline

Purcell AL, Sharma SK, Bagnall MW, Sutton MA, Carew TJ (2003) Activation of a tyrosine kinase-MAPK cascade enhances the induction of longterm synaptic facilitation and long-term memory in Aplysia. Neuron 37: 473-484. CrossRef Medline

Rajasethupathy P, Fiumara F, Sheridan R, Betel D, Puthanveettil SV, Russo JJ, Sander C, Tuschl T, Kandel E (2009) Characterization of small RNAs in Aplysia reveals a role for miR-124 in constraining synaptic plasticity through CREB. Neuron 63:803-817. CrossRef Medline

Rajasethupathy P, Antonov I, Sheridan R, Frey S, Sander C, Tuschl T, Kandel ER (2012) A role for neuronal piRNAs in the epigenetic control of memory-related synaptic plasticity. Cell 149:693-707. CrossRef Medline

Royer S, Coulson RL, Klein M (2000) Switching off and on of synaptic sites at Aplysia sensorimotor synapses. J Neurosci 20:626-638. Medline

Ruben P, Johnson JW, Thompson S (1986) Analysis of FMRFamide effects on Aplysia bursting neurons. J Neurosci 6:252-259. Medline

Sacktor TC (2011) How does PKMzeta maintain long-term memory? Nat Rev Neurosci 12:9-15. CrossRef Medline

Sacktor TC, Kruger KE, Schwartz JH (1988) Activation of protein kinase C by serotonin: biochemical evidence that it participates in the mechanisms underlying facilitation in Aplysia. J Physiol (Paris) 83:224-231. Medline

Schaffhausen JH, Fischer TM, Carew TJ (2001) Contribution of postsynaptic $\mathrm{Ca}^{2+}$ to the induction of post-tetanic potentiation in the neural circuit for siphon withdrawal in Aplysia. J Neurosci 21:1739-1749. Medline

Sharma SK, Sherff CM, Shobe J, Bagnall MW, Sutton MA, Carew TJ (2003) Differential role of mitogen-activation protein kinase in three distinct phases of memory for sensitization in Aplysia. J Neurosci 23:3899-3907. Medline

Sherff CM, Carew TJ (2002) Coincident induction of long-term facilitation at sensory-motor synapses in Aplysia: presynaptic and postsynaptic factors. Neurobiol Learn Mem 78:498-507. CrossRef Medline

Sherff CM, Carew TJ (2004) Parallel somatic and synaptic processing in the induction of intermediate-term and long-term synaptic facilitation in Aplysia. Proc Natl Acad Sci U S A 101:7463-7468. CrossRef Medline

Si K, Choi YB, White-Grindley E, Majumdar A, Kandel ER (2010) Aplysia $\mathrm{CPEB}$ can form prion-like multimers in sensory neurons that contribute to long-term facilitation. Cell 140:421-435. CrossRef Medline

Small SA, Cohen TE, Kandel ER, Hawkins RD (1992) Identified FMRFamideimmunoreactive neuron LPL16 in the left pleural ganglion of Aplysia pro- duces presynaptic inhibition of siphon sensory neurons. J Neurosci 12:16161627. Medline

Sossin WS, Kirk MD, Scheller RH (1987) Peptidergic modulation of neuronal circuitry controlling feeding in Aplysia. J Neurosci 7:671-681. Medline

Stoica L, Zhu PJ, Huang W, Zhou H, Kozma SC, Costa-Mattioli M (2011) Selective pharmacogenetic inhibition of mTORC1 blocks long-term synaptic plasticity and memory storage. Proc Natl Acad Sci U S A 108:37913796. CrossRef Medline

Sugita S, Goldsmith JR, Baxter DA, Byrne JH (1992) Involvement of protein kinase $\mathrm{C}$ in serotonin-induced spike broadening and synaptic facilitation in sensorimotor connections of Aplysia. J Neurophysiol 68:643-651. Medline

Sun ZY, Schacher S (1996) Development of short-term heterosynaptic facilitation at Aplysia sensorimotor synapses in vitro is accompanied by changes in the functional expression of presynaptic serotonin receptors. J Neurophysiol 76:2250-2261. Medline

Sutton MA, Ide J, Masters SE, Carew TJ (2002) Interaction between amount and pattern of training in the induction of intermediate- and long-term memory for sensitization in Aplysia. Learn Mem 9:29-40. CrossRef Medline

Sweatt D, Volterra A, Siegelbaum SA, Kandel ER (1989) Molecular convergence of presynaptic inhibition and presynaptic facilitation on common substrate proteins of individual sensory neurons of Aplysia. Cold Spring Harb Synp Quant Biol 53:395-405. Medline

Tronson NC, Wiseman SL, Olausson P, Taylor JR (2006) Bidirectional behavioral plasticity of memory reconsolidation depends on amygdalar protein kinase A. Nat Neurosci 9:167-169. CrossRef Medline

Trudeau LE, Castellucci VF (1995) Postsynaptic modifications in long-term facilitation in Aplysia: upregulation of excitatory amino acid receptors. J Neurosci 15:1275-1284. Medline

Upadhya SC, Ding L, Smith TK, Hegde AN (2006) Differential regulation of proteasome activity in the nucleus and the synaptic terminals. Neurochem Int 48:296-305. CrossRef Medline

Villareal G, Li Q, Cai D, Glanzman DL (2007) The role of rapid, local, postsynaptic protein synthesis in learning-related synaptic facilitation in Aplysia. Curr Biol 17:2073-2080. CrossRef Medline

Wainwright ML, Zhang H, Byrne JH, Cleary LJ (2002) Localized neuronal outgrowth induced by long-term sensitization training in Aplysia. J Neurosci 22:4132-4141. Medline

Wu F, Schacher S (1994) Pre- and postsynaptic changes mediated by two second messengers contribute to expression of long-term heterosynaptic inhibition in Aplysia. Neuron 12:407-421. CrossRef Medline

Xu Y, Cleary LJ, Byrne JH (1994) Identification and characterization of pleural neurons that inhibit tail sensory neurons and motor neurons in Aplysia: correlation with FMRFamide immunoreactivity. J Neurosci 14: 3565-3577. Medline

Zhang F, Goldsmith JR, Byrne JH (1994) Neural analogue of long-term sensitization training produces long-term ( 24 and $48 \mathrm{~h}$ ) facilitation of the sensory-to-motor neuron connection in Aplysia. J Neurophysiol 72:778 784. Medline

Zhang Y, Smolen P, Baxter DA, Byrne JH (2010) The sensitivity of memory consolidation and reconsolidation to inhibitors of protein synthesis and kinases: computational analysis. Learn Mem 17:428-439. CrossRef Medline

Zhao Y, Klein M (2002) Modulation of the readily releasable pool of transmitter and of excitation-secretion coupling by activity and by serotonin at Aplysia sensorimotor synapses in culture. J Neurosci 22:10671-10679. Medline

Zhao Y, Hegde AN, Martin KC (2003) The ubiquitin proteasome system functions as an inhibitory constraint on synaptic strengthening. Curr Biol 13:887-898. CrossRef Medline

Zhu H, Wu F, Schacher S (1997) Site-specific and sensory neurondependent increases in postsynaptic glutamate sensitivity accompany serotonin-induced long-term facilitation at Aplysia sensorimotor synapses. J Neurosci 17:4976-4986. Medline 